\title{
Rice husk as renewable energy for biogas production from biomass: prospect and challenges
}

\author{
Ayudya Izzati Dyah Lantasi ${ }^{*}$, Syafrudin, and Budiyono \\ Master Program of Environmental Science, School of Postgraduate, Diponegoro University, \\ Indonesia
}

\begin{abstract}
Greenhouse gas emissions go hand in hand with fossil energy consumption. The use of fossil energy has increased sharply in the past 15 years. Biogas is one of renewable energy derived from biomass that can overcome greenhouse gas emissions and reduce the generation of organic solid waste. Some materials with high lignin content are good substrates to increase biogas production. Rice husk is a potential material to be used as a biogas substrate and it is quite abundant in Indonesia. However, its utilization for full scale operation has not been maximized. This review article will discuss the potential of rice husks as substrates and prospects in their implementation including various characteristics, influence factors to optimize and up-scale the biogas production. Further research is needed to increase biogas production and overcome existing obstacles.
\end{abstract}

Keywords: Rice Husk, Biogas, Co-digestion, Renewable Energy

\section{Introduction}

The fossil energy used to this day still dominates world energy consumption. Its availability is expected to reach scarcity. Efforts to develop renewable energy sources that are more environmentally friendly and meet the aspects of water, wind and biomass-based energy sustainability are continuing. Biomass energy derived from agricultural waste has great potential because its availability coincides with the food needs of the world's population. Utilization of biomass waste will not only increase the resilience of the agriculture and forestry sector systems but will also reduce dependence on fossil energy and reduce greenhouse gas emissions. This biomass energy is then processed into biogas which can be used as fuel for motor vehicles and power plants [1].

* Corresponding author: ayudyaaa@gmail.com 
Biogas is a second generation biomass waste conversion product as a renewable energy source. Biogas is methane gas produced from biomass waste decomposition. Bioenergy generated from agricultural waste is considered to be able to contribute to reducing methane emissions from organic sources and fossil fuel substitution [2]. In general, biogas is produced through anaerobic processes that break down the constituent components of biomass. Biogas technology has been developed in Indonesia by using raw materials for animal manure. However, other potential in the form of agricultural biomass waste has not been utilized optimally as a renewable energy source.

The availability of rice as one of the staples in Indonesia is quite abundant. In 2018 rice production in Central Java Province reach 9 million tons of dry milled un-hulled rice [3]. The high number also shows that the waste generated from rice production is quite high but its utilization has not been optimized. Rice production waste, especially rice husk, is a material that has a high lignocellulosic content. However, high lignocellulosic content can inhibit biogas production so it needs to be overcome with various efforts such as involving co-substrate in the biogas production process and providing pre-treatment on the biomass substrate.

Co-substrate acts as a counterweight to the production process factors [4]. Various studies related to the use of co-substrate in the production of biogas based on biomass have been carried out. In addition to the use of co-substrates, an increase in biogas production can also be done by giving pre-treatment to the biomass substrate. Pre-treatment is considered capable of breaking the bonds of lignocellulose compounds in biomass thereby increasing biogas production (Figure 1). The various studies then encourage other studies by using both methods to overcome the characteristics of biomass waste.

This article is a review of various studies related to biomass and rice-based biogas with the use of co-substrates and other factors influencing biogas production. This article will also discuss the results of various biogas studies from biomass waste, the efforts needed to improve the quality of biogas production.

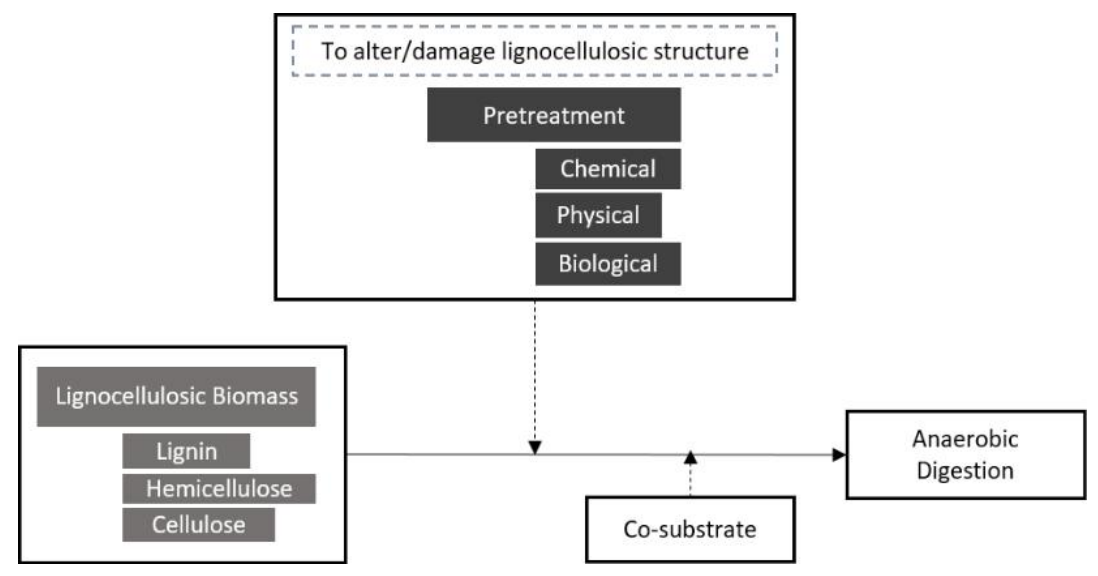

Figure 1. Steps involved to produce biogas from lignocellulosic biomass 


\section{Rice husk characteristics}

Rice husk is agricultural waste that cannot be consumed so that it is not further processed after harvesting. Most farmers only accumulate and burn rice husk waste without further utilization. This can cause other environmental problems such as piles of waste that can damage soil quality and greenhouse gas emissions into the atmosphere. Even though rice husk is one of the biomass raw materials that can be utilized. Biomass is a renewable energy source that is rich in carbon content so that it is potential to be used and processed as fuel and other environmentally friendly materials such as bricks [5]. Agricultural waste, especially rice husk, is one type of waste produced as a result of human activities so that it can be categorized as an appropriate alternative for bioenergy production.

General characteristics of rice husks are the raw material for lignocellulosic biomass because they are mostly composed of cellulose, hemicellulose and lignin (Table 1). These three compounds cause lignocellulosic biomass to have a low level of biodegradation due to the crystalline structure of lignin which envelops cellulose and hemicellulose. The structure must be broken down so that the hydrolysis process can run faster [6].

Table 1. Characteristic of Rice Waste (\%) [7, 10]

\begin{tabular}{|l|l|l|}
\hline & Rice Husk & Rice Straw \\
\hline Cellulose & 34.4 & 44.3 \\
\hline Hemicellulose & 29.3 & 35.5 \\
\hline Lignin & 19.2 & 20.4 \\
\hline Proximate analysis (dry basis) & & \\
\hline Fixed carbon & 16.22 & 15.86 \\
\hline Volatile matter & 63.52 & 65.47 \\
\hline Ash & 20.26 & 18.67 \\
\hline Ultimate analysis (dry basis) & & \\
\hline Carbon & 38.53 & 38.24 \\
\hline Hydrogen & 4.75 & 5.20 \\
\hline Oxygen & 35.47 & 36.26 \\
\hline Nitrogen & 0.52 & 0.87 \\
\hline Sulphur & 0.05 & 0.18 \\
\hline Higher heating value (MJ/kg) & 15.84 & 15.09 \\
\hline
\end{tabular}




\section{Anaerobic co-digestion}

Anaerobic process is a complex system and responsive to the presence of various kinds of microbes during the process. Biogas is a product of anaerobic processes that break down organic compounds with the help of microbes without the presence of oxygen. Biogas generally contains as much as $50-70 \% \mathrm{CH} 4, \mathrm{CO} 2$ as much as $20-45 \%$ and other gases. In general, degradation of organic material through anaerobic processes to produce biogas through the stages of hydrolysis, acidogenesis, acetogenesis and methanogenesis. The whole process involves microorganisms that are very diverse with their respective functions at each stage [6]. The anaerobic process uses only a single substrate. However, the use of substrates more than 1 is able to maintain a more stable process. Anaerobic codigestion technology uses various types of biomass waste as a substrate or raw material to produce methane gas. Various studies have been carried out to find out various codigestion mixtures using industrial, agricultural, livestock and domestic waste to increase biogas and methane production [11].

Anaerobic co-digestion is an effort to optimize biogas production by mixing two or more substrates. The benefits of anaerobic co-digestion are that it increases the stability of the process, weakens the inhibitory effect, the moisture content in the digester is more stable, increases the synergy of microorganisms, and reduces greenhouse gas emissions [4, 11]. The quality of raw materials and environmental conditions need to be adjusted to design an appropriate reactor / digester so that the production of methane gas can be optimized. Based on several studies it is known that co-substrates suitable for agricultural waste are co-substrates which have high nitrogen content and are easily degraded. Factors in the biogas production process in general such as the $\mathrm{C} / \mathrm{N}$ ratio, $\mathrm{pH}$, and alkalinity need to be considered to determine the ratio of co-substrate used.

Lignocellulosic biomass has a high organic load, microbial diversity and low nitrogen content. These factors are potential inhibitors of the anaerobic digestion process. Agricultural waste that does not involve co-substrates in the biogas production process will produce low biogas. The high $\mathrm{C} / \mathrm{N}$ ratio and the high percentage of lignin and pesticide contamination can affect the biogas production process. These obstacles can be overcome by adding co-substrate to the reactor. This method is considered to be able to increase biogas production to more than $20 \% \mathrm{CH} 4$ than predicted $[6,12]$. Various studies have been carried out related to the use of co-substrates in the production of biogas with biomass substrates. Livestock waste such as chicken manure [13], goat [14, 15], cattle [6, $16,17]$, domestic wastewater [18] and food scraps [19, 20] are widely used as biomass waste co-substrate for biogas production. While the research specifically for co-substrate of rice husk is manure such as cows, pigs, and chickens, and tofu industry liquid waste (Table 2). 
Table 2. Anaerobic co-digestion of rice husk in previous research

\begin{tabular}{|l|c|c|c|}
\hline \multicolumn{1}{|c|}{ Substrate } & Process Condition & Result & Refference \\
\hline Food Waste:Rice Husk & Continues & $82 \%$ VS removal & {$[19]$} \\
\hline Cow Dung:Rice Husk & $\begin{array}{c}\text { Rice Husk not } \\
\text { pretreated }\end{array}$ & $\begin{array}{c}\text { Not significant, highest biogas } \\
\text { yield for TS 40\% }\end{array}$ & {$[21]$} \\
\hline Rice Husk:Cow Dung & $\begin{array}{c}\text { Adding EM-4, TS and } \\
\text { stirring variation }\end{array}$ & $\begin{array}{c}\text { Highest biogas yield for TS } \\
20 \%+\text { EM-4+stirring }\end{array}$ & {$[22]$} \\
\hline $\begin{array}{l}\text { Tofu Liquid Waste:Rice } \\
\text { Husk }\end{array}$ & $\begin{array}{c}\text { Fixed dome reactor, } \\
\text { batch, EM-4 as starter }\end{array}$ & $\begin{array}{c}\text { Methane started to form on the } \\
14^{\text {th }} \text { day }\end{array}$ & {$[23]$} \\
\hline Cow Dung:Rice Husk & $\begin{array}{c}\text { Varying prorportion } \\
\text { of biomass }\end{array}$ & $\begin{array}{c}50: 50 \text { proportion produced the } \\
\text { highest cumulative yield }\end{array}$ & {$[24]$} \\
\hline $\begin{array}{l}\text { Thai Rice } \\
\text { Wastewater:Rice }\end{array}$ & $\begin{array}{c}\text { Batch, different type } \\
\text { of manure, ash } \\
\text { supplement as trace } \\
\text { elements }\end{array}$ & $\begin{array}{c}\text { Thai rice noodle+rice } \\
\text { husk+Chicken manure+ } 6 \\
\text { gram of ash produce the } \\
\text { highest yield }\end{array}$ & {$[25]$} \\
\hline
\end{tabular}

\section{Pre-treatment}

Lignin compounds in biomass can inhibit hydrolysis or breakdown of cellulose and hemicellulose compounds. Therefore various techniques were developed to facilitate the anaerobic process of biomass to produce biogas. Pre-treatment technique is one way to simplify the process of biogas production with lignocellulosic biomass substrate. This technique is broadly divided into two groups, namely non-biological and biological pretreatment. Non-biological pre-treatment takes place without the help of microbes and is divided into several categories, namely physical, chemical, physico-chemical, and biological pre-treatment. Each type of pre-treatment has

Pre-treatment is a special process that can work on certain substrates. Optimum results obtained on one biomass substrate with pre-treatment may be different on other biomass substrates with the same pre-treatment. So it is necessary to know more about the effectiveness of pre-treatment of certain biomass substrates through selective selection of the characteristics of each biomass. Pre-treatment of lignocellulosic raw materials is one of the important steps to change the structure of biomass waste and to break lignocellulosic bonds so that the process of reducing sugar takes place more easily [26]. 


\section{Factor effecting anaerobic co-digesting}

\subsection{Co-substrate characteristic}

Understanding the specific characteristics of the co-substrate that will be used in the biogas production process is one of the important things. The characteristics of the ingredients can determine the product produced from the anaerobic process. The chemical composition of an ingredient is important to know because it will determine its ability to produce biogas.

The characteristics of each material are different so the choice of co-substrate must be adjusted to the characteristics of the main substrate. The content of the constituent ingredients will differ from one another so biogas production conditions can be affected. Carbohydrate-rich production materials are one example of materials used for biogas production. Plant substrate and its derivative products are one of the ingredients that are rich in carbohydrates. Other materials used as ingredients for biogas production are materials with high protein content. Materials with high protein content have the potential to produce methane in the biogas production process [11].

The characteristics of the material used will affect the stability of the anaerobic biogas system. If the material contains one specific compound that is too much then the system's stability factors will be easily disturbed. Carbohydrates on the substrate will be broken down through the process of acidogenesis to form volatile fatty acids (VFA). The higher the sugar content in a substrate, the formation of VFA will also increase and decrease the $\mathrm{pH}$ value while the protein content that is too high can form inhibiting compounds, namely ammonia

\section{$5.2 \mathrm{C} / \mathrm{N}$ ratio and $\mathrm{pH}$}

Comparison of carbon to nitrogen content or $\mathrm{C} / \mathrm{N}$ ratio on a substrate can affect the overall anaerobic process, especially the anaerobic co-digestion process. Substrate with an optimal $\mathrm{C} / \mathrm{N}$ ratio can meet nutrients for microorganisms so that optimum biogas production. A low $\mathrm{C} / \mathrm{N}$ ratio can increase the ammonia content and inhibit the growth of microorganisms. Whereas a high $\mathrm{C} / \mathrm{N}$ ratio can increase VFA production [11]. Based on research the optimal $\mathrm{C} / \mathrm{N}$ value is 33.45 with TS $<15 \%$ [27]. Another thing related to the operational process of the digester is the $\mathrm{pH}$ value.

The $\mathrm{pH}$ value is one of the factors that affect the anaerobic system because it determines the solubility of organic compounds. In addition, $\mathrm{pH}$ also affects the life of microorganisms, especially enzymatic reactions. In the biogas production process, $\mathrm{pH}$ significantly influences the fermentation process because each type of microorganism that plays a role in the biogas process can only live in a certain $\mathrm{pH}$ range. Research shows that maintaining a $\mathrm{pH}$ range of 6.8-7.2 can support the biogas production process which is the optimum $\mathrm{pH}$ for microorganisms of methanogenesis. However, hydrolysis and acidogenesis microorganisms can work optimally at $\mathrm{pH}$ 5.5-6.5 [11]. 


\subsection{Temperature}

Temperature is one of the important factors in the biogas production process. The selection and regulation of the right temperature in the anaerobic process can increase biogas production. Anaerobic processes can take place in the range of psychrophilic, mesophilic and thermophilic temperatures. The mesophilic temperature range which is at $35^{\circ} \mathrm{C}$ is commonly used because in that temperature range more microorganisms that can live and pathogens that die so that supports anaerobic processes for biogas production. The mesophilic process is considered more stable than thermophilic. An increase in temperature in the anaerobic process will also increase the metabolism of microorganisms and accelerate the degradation process. However, the system will be more difficult to control as well as in the thermophilic temperature range. Also in the thermophilic temperature range ammonia is more easily formed so that it can inhibit the degradation process and make the process unstable. The optimum conditions for methane production are in the range $32-35^{\circ} \mathrm{C}[11,28]$.

\section{Discussion: future prospect and challenges}

Previous studies have shown the potential of rice husks to be used as biogas substrates. Rice husk is produced as a by-product of rice production. As much as $20 \%$ of rice production is rice husk [29]. The rice husk produced is generally burned or simply piled without further processing. Rice husk in Indonesia until now is widely used as a planting medium and fertilizer. If seen based on its chemical characteristics, rice husks have the potential to be used as a renewable energy source.

Utilization of rice husk waste into energy sources will benefit the environment. Rice husk waste that is stacked and burned will certainly emit greenhouse gas emissions that are harmful to the environment. Based on studies of greenhouse gases released into the environment from agricultural waste is $53 \%$ of the average GWP [30]. Utilization of rice husks by processing them into energy sources will certainly be more useful. Based on research adoption of biogas technology affects the use of firewood as stove fuel used in the kitchen so that it is more environmentally friendly [31]

However, the production and availability of rice husks will depend on the production of rice plants. Rice husk production will decrease if rice production decreases and vice versa. Rice production is also influenced by various factors such as weather, land conditions and pests. Based on data from the Central Statistics Agency or Badan Pusat Statistik (BPS), Indonesia's rice production until 2015 has increased. Throughout 2018 rice production in Central Java reached 9 million tons of dry grain [3]. One of the factors that affects the availability of materials is data related to their availability and utilization [32]. Data that is widely used in various studies is data obtained from assumptions based on research conducted in different places or countries with study locations. This can be influential because the production of each country or place is different from one another. Besides the availability of material is also influenced by the level of utilization of it into other products. The processing factor for grain waste in developed and developing countries will be different. So empirical data based on the results of research related to the availability of materials is needed so that the sustainability of production can be measured accurately. 
The characteristics of rice husks that have high lignocellulosic content have also been overcome by using pre-treatment techniques that can be carried out chemically, physically and biologically. Pre-treatment techniques have shown the results that with pre-treatment of biogas production with rice husk material can be increased. The characteristic of strong lignocellulosic material causes the pre-treatment process to be one of the steps that needs to be done to optimize biogas production. In addition to pre-treatment, biogas production can also be increased by adding co-substrates as an alternative to increasing nutrients for microorganisms during the anaerobic process. The addition of the substrate in addition to increasing biogas production is also able to stabilize the production process.

However, most of the previous studies were limited to laboratory-scale research. Most of the researches in laboratory-scale are not evaluate the environmental risk from the process. The pre-treatment stage which is carried out before the anaerobic process begins certainly requires chemicals and energy sources. This will not have a big effect if production is carried out on a small scale or on a laboratory scale. If the scale of biogas production is increased, of course the amount of material and the amount of energy needed will increase. Further analysis related to energy consumption and the impact on the environment is certainly needed so that biogas production can be used massively [28]. Therefore, we need a pre-treatment process that uses a low amount of energy and environmental friendly but able to break the bonds of lignocellulosic compounds.

\section{Conclusion and recommendation}

Agricultural waste, one of which is rice husk, is one waste that has a great opportunity to be utilized as a renewable energy source. The content of lignocellulose which compiles rice husk makes rice husk has the potential to be processed into an energy source as well as an obstacle in its processing. Various studies have been done before to be able to process rice husks into energy sources that can be utilized by the wider community. The pre-treatment process and the addition of substrates in the anaerobic process are considered good ways to increase biogas production from rice husks.

However, research on biogas from rice husks has not been done up-scale. Pre-treatment techniques that need to be done on rice husks require a large amount of material and energy that will have an impact on the environment. Various studies are still needed further research both at the laboratory scale up to full scale so that the impact to the environment can be reduced.

\section{References}

[1] X. Ge, F. Xu, and Y. Li, Solid-state anaerobic digestion of lignocellulosic biomass: Recent progress and perspectives, Bioresour. Technol., vol. 205, pp. 239-249, (2016)

[2] A. Haryanto, F. Marotin, S. Triyono, and U. Hasanudin, Developing A Family-Size BiogasFueled Electricity Generating System, International Journal of Renewable Energy Development, vol. 6, no. 2, pp. 111-118, (2017)

[3] BPS, Luas Panen dan Produksi Padi di Jawa Tengah 2018, no. 61. (2018) 
[4] J. Kainthola, A. S. Kalamdhad, and V. V. Goud, A review on enhanced biogas production from anaerobic digestion of lignocellulosic biomass by different enhancement techniques, Process Biochem., vol. 84, no. January, pp. 81-90, (2019)

[5] H. H. A. Matin and Hadiyanto, Biogas Production from Rice Husk Waste by using Solid State Anaerobic Digestion (SSAD) Method, E3S Web Conf., vol. 31, (2018)

[6] Avicenna, M. Mel, S. I. Ihsan, and R. H. Setyobudi, Process Improvement of Biogas Production from Anaerobic Co-digestion of Cow Dung and Corn Husk, Procedia Chem., vol. 14, pp. 91-100, (2015)

[7] Y.-F. Huang and S.-L. Lo, Utilization of rice hull and straw. AACCI. Published by Elsevier Inc. in cooperation with AACC International, (2019)

[8] B. lin Dai, X. jing Guo, D. hai Yuan, and J. ming Xu, Comparison of Different Pretreatments of Rice Straw Substrate to Improve Biogas Production, Waste and Biomass Valorization, vol. 9, no. 9, pp. 1503-1512, (2018)

[9] D. Kumari and R. Singh, Pretreatment of lignocellulosic wastes for biofuel production: A critical review, Renew. Sustain. Energy Rev., vol. 90, no. March, pp. 877-891, (2018)

[10] J. S. Lim, Z. Abdul Manan, S. R. Wan Alwi, and H. Hashim, A review on utilisation of biomass from rice industry as a source of renewable energy, Renew. Sustain. Energy Rev., vol. 16, no. 5, pp. 3084-3094, (2012)

[11] M. N. I. Siddique and Z. A. Wahid, Achievements and perspectives of anaerobic codigestion: A review, J. Clean. Prod., vol. 194, no. 1, pp. 359-371, (2018)

[12] I. A. Fotidis, T. F. V. C. Laranjeiro, and I. Angelidaki, Alternative co-digestion scenarios for efficient fixed-dome reactor biomethanation processes, J. Clean. Prod., vol. 127, pp. 610617, Jul. (2016)

[13] X. Wang, G. Yang, Y. Feng, G. Ren, and X. Han, Optimizing feeding composition and carbon-nitrogen ratios for improved methane yield during anaerobic co-digestion of dairy, chicken manure and wheat straw, Bioresour. Technol., vol. 120, pp. 78-83, (2012)

[14] J. H. Patil, M. A. L. AntonyRaj, B. B. Shankar, M. K. Shetty, and B. P. Pradeep Kumar, Anaerobic co-digestion of Water Hyacinth and Sheep Waste, Energy Procedia, vol. 52, pp. 572-578, (2014)

[15] T. Cestonaro et al., The anaerobic co-digestion of sheep bedding and $\geq 50 \%$ cattle manure increases biogas production and improves biofertilizer quality, Waste Manag., vol. 46, pp. 612-618, (2015)

[16] F. Tasnim, S. A. Iqbal, and A. R. Chowdhury, Biogas production from anaerobic codigestion of cow manure with kitchen waste and Water Hyacinth, Renew. Energy, vol. 109, pp. 434-439, (2017)

[17] Y. Yao, S. Chen, and G. K. Kafle, Importance of 'weak-base' poplar wastes to process performance and methane yield in solid-state anaerobic digestion, J. Environ. Manage., vol. 193, pp. 423-429, (2017)

[18] P. C. Chan, R. A. De Toledo, H. In Iu, and H. Shim, Co-digestion of food waste and domestic wastewater - Effect of copper supplementation on biogas production, Energy Procedia, vol. 153, pp. 237-241, (2018)

[19] M. Jabeen, Zeshan, S. Yousaf, M. R. Haider, and R. N. Malik, High-solids anaerobic codigestion of food waste and rice husk at different organic loading rates, Int. Biodeterior. Biodegrad., vol. 102, pp. 149-153, (2015)

[20] H. Zhang, L. Luo, W. Li, X. Wang, Y.Sun, Y. Sun, W. Gong, Optimization of mixing ratio of ammoniated rice straw and food waste co-digestion and impact of trace element supplementation on biogas production, J. Mater. Cycles Waste Manag., vol. 20, no. 2, pp. 745-753, (2018) 
[21] S. S. Mulyawan, D.W. Aghnia, E. Rianawati, E. Damanhuri, M. Handjani, T. Padmi, B.C.L. Fui, M. Acda, P. Unrean, The Study of Rice Husk as Co-Digestion Together with Cow Dung is Biogas Production of Anaerobic Digester, E3S Web Conf., vol. 73, (2018)

[22] L. Asiyanthi Tabran, A. Abdul Nasser, and Nurhayati, Effect of Bio-activator Addition and Stirring on Biogas Production from Rice Husks and Cow Dung, E3S Web Conf., vol. 73, pp. 6-10, (2018)

[23] J. Wahyudi, T. B. Achmad Kurnani, and J. Clancy, Biogas Production in Dairy Farming in Indonesia: A Challenge for Sustainability, International Journal of Renewable Energy Development, vol. 4, no. 3, pp. 219-226, (2015).

[24] E. T. Iyagba, I. A. Mangibo, and Y. S. Mohammad, The study of cow dung as co-substrate with rice husk in biogas production, Sci. Res. Essays, vol. 4, no. 9, pp. 861-866, (2009)

[25] S. Jijai, S. Muleng, L. Noynoo, and C. Siripatana, Kinetic model of biogas production from co-digestion of Thai rice noodle wastewater with rice husk and different type of manure with ash supplement, IOP Conf. Ser. Earth Environ. Sci., vol. 463, no. 1, (2020)

[26] A. K. Kumar and S. Sharma, Recent updates on different methods of pretreatment of lignocellulosic feedstocks: a review, Bioresour. Bioprocess., vol. 4, no. 1, (2017)

[27] W. D. Nugraha, Syafrudin, V. N. Kusumastuti, H. H. A. Matin, and Budiyono, Optimization of biogas production in Indonesian region by liquid anaerobic digestion ( $L-A D)$ method from rice husk using response surface methodology (RSM), IOP Conf. Ser. Mater. Sci. Eng., vol. 845, p. 012042, (2020)

[28] S. Mothe and V. R. Polisetty, Review on anaerobic digestion of rice straw for biogas production, Environ. Sci. Pollut. Res., Apr. (2020)

[29] E. R. Abaide, M. V. Tres, G. L. Zabot, and M. A. Mazutti, Reasons for processing of rice coproducts: Reality and expectations, Biomass and Bioenergy, vol. 120, no. March 2018, pp. 240-256, (2019)

[30] H. Pathak and R. Wassmann, Introducing greenhouse gas mitigation as a development objective in rice-based agriculture: I. Generation of technical coefficients, Agric. Syst., vol. 94, no. 3, pp. 807-825, (2007)

[31] R. Ahmad Romadhoni Surya Putra, Z. Liu, and M. Lund, The impact of biogas technology adoption for farm households - Empirical evidence from mixed crop and livestock farming systems in Indonesia, Renew. Sustain. Energy Rev., vol. 74, no. November, pp. 1371-1378, (2017)

[32] I. Nygaard, F. Dembelé, I. Daou, A. Mariko, F. Kamissoko, N. Coulibaly, R.L. Borgstrøm, T.B. Bruun, Lignocellulosic residues for production of electricity, biogas or second generation biofuel: A case study of technical and sustainable potential of rice straw in Mali, Renew. Sustain. Energy Rev., vol. 61, pp. 202-212, (2016) 